\title{
PENGGUNAAN GOOGLE FORM DALAM EVALUASI HASIL BELAJAR PESERTA DIDIK DI MASA PANDEMI COVID-19
}

\author{
LINA WAHYU SETYA UTAMI \\ SMA Negeri 1 Candiroto Kab.Temanggung Jawa Tengah \\ Email : linawahyu219@gmail.com
}

\begin{abstract}
ABSTRAK
Artikel penelitian ini bertujuan untuk mendeskripsikan mengenai keefektifan pemanfaatan Google Form dalam pelaksanaan evaluasi hasil belajar peserta didik di masa pandemi Covid19. Fitur yang di teliti fokusnya adalah penggunaan aplikasi Google Form sebagai alat evaluasi hasil belajar siswa. Dalam pembelajaran diperlukan evaluasi untuk mengetahui hasil dari proses belajar peserta didik, yang semula evaluasi dilaksanakan secara tatap muka dengan media kertas sementara di masa pandemi Covid-19 ini, evaluasi secara konvensional tidak bisa dilakukan karena dituntut untuk melakukan pembelajaran secara daring atau pembelajaran jarak jauh. Peningkatan penggunaan pembelajaran online memberikan tantangan bagi para pendidik dan peserta didik untuk memilih metode yang tepat untuk memfasilitasi peserta didik dalam pembelajaran daring khususnya dalam hal penilaian. Penggunaan aplikasi Google Form dalam kegiatan evaluasi hasil belajar siswa ternyata sangat efektif .Penelitian ini menggunakan pendekatan kualitatif dengan metode angket ada 35 siswa yang menjadi responden dan memberikan tanggapan positif dengan perolehan skor $71.50 \%$ berkategori baik. Hasil ini membuktikan bahwa penggunaan Google Form sebagai media untuk melaksanakan evaluasi hasil belajar siswa adalah efektif di tengah-tengah masa pandemi Covid-19 yang pembelajarannya tidak bisa dilakukan dengan tatap muka akan tetapi secara daring.
\end{abstract}

Kata Kunci : Covid-19, Google Form, Evaluasi.

\section{PENDAHULUAN}

Sudah dua tahun pelaksanaan pembelajaran di Indonesia dilakukan secara daring. Pada tanggal 02 Maret 2020 untuk pertama kalinya pemerintah Indonsia mengumukan dua kasus pasien positif Covid -19 di Indonesia. Kebijakan PPKM yang diambil pemerintah untuk membatasi kegiatan masyarakat agar rantai penularan Covid -19 terputus. Perpanjangan system kerja ASN di lingkungan pemerintah provinsi Jawa Tengah selama PPKM pada masa pandemi Corona Virus Disease 2021 dilakukan khususnya di kabupaten Temanggung yang termasuk level 3 maka sebanyak $75 \%$ dari seluruh ASN menjalankan tugas kedinasan bekerja dari rumah atau tempat tinggalnya (work from home) dengan tetap memperhatikan sasaran kinerja dan target pegawai yang bersangkutan.

Akibat dari kebijakan ini banyak sekolah yang semula berencana mengadakan pembelajaran tatap muka akhirnya menunda kembali pelaksanaannya, dan kembali menggunakan pembelajaran dengan metode online atau daring ( dalam jaringan ). Kondisi pandemi Covid 19 dengan varian baru yang kian merebak membuat opsi pembelajaran online yang paling memungkinkan untuk dilaksanakan.

Penggunaan Teknologi Informasi (TI) dalam pembelajaran dianggap sebagai salah satu alternatif menyikapi dalam kondisi khusus dan membawa perubahan tradisi atau budaya pembelajaran serta menjadi sistem pembelajaran mandiri. Model pembelajaran yang berhubungan dengan TI dan kini menjadi perhatian dunia pendidikan adalah model pembelajaran berbasis komputer dan pembelajaran melalui media elektonik berbasis web base learning (Wena, 2009).

E-Learning merupakan sebuah proses pembelajaran berbasisi elektronik dalam penggunaannya dapat diakses online (Weni \& Isnani, 2016). Meningkatkan penguasaan terhadap materi pembelajaran, meningkatkan interaksi antara peserta didik kepada pendidik dan memudahkan pada proses pembelajaran merupakan tujuan yang dimiliki e-Learning dalam penerapannya (Darmayanti et al., 2007). Sehingga efektif digunakan dalam masa pandemi ini. 


\section{TEACHING : Jurnal Inovasi Keguruan dan IImu Pendidikan Vol. 1. No. 3 September 2021 e-ISSN : 2775-7188 | p-ISSN : 2775-717X}

Evaluasi hasil belajar pada dasarnya merupakan salah satu bagian dari evaluasi pendidikan. Evaluasi hasil belajar bukan saja pada luaran namun juga meliputi proses belajar mengajar. Kemudian evaluasi hasil belajar, bukan hanya evaluasi yang dilakukan di dalam kelas, juga kegiatan pembelajaran yang dilakukan dimanapun (Matondang et al., 2019). Jadi evaluasi hasil belajar tidak hanya fokus dari luaran pembelajaran di kelas, namun lebih luas dari berbagai macam kegiatan pembelajaran dimanapun diselenggarakan.

Menurut Stufflebeam dan Shinkfield (dalam Matondang et al.,2019), Evaluasi merupakan suatu proses menyediakan informasi yang dapat dijadikan sebagai pertimbangan untuk menentukan harga dan jasa (the wort and merit) dan tujuan yang dicapai, desain, implementasi dan dampak untuk membantu membuat keputusan membantu pertanggungjawaban dan meningkatkan pemahaman terhadap fenomena. Menurut rumusan tersebut, inti dari evaluasi adalah penyediaan informasi yang dapat dijadikan sebagai bahan pertimbangan dalam mengambil keputusan.

Dalam pembelajaran diperlukan evaluasi untuk mengetahui seberapa efektif proses pembelajaran yang telah diterapkan kepada peserta didik. Secara konvensional evaluasi pembelajaran dilakukan secara tes tertulis, dengan perangkat yang terdiri dari lembar soal dan lembar jawaban. Setelah itu guru harus memeriksa setiap lembar jawaban untuk mengetahui hasil evaluasi proses pembelajaran. Tentu saja hal ini sangat menyita banyak waktu dan tenaga. Pada perkembangan teknologi dan informasi yang sangat pesat dapat memberikan banyak kemudahan di berbagai bidang khususnya bidang pendidikan. Pada masa pandemi sekarang sekolah diminta untuk melakukan pencegahan penyebaran Covid-19, WHO merekomendasikan untuk menghentikan sementara kegiatan kegiatan yang berpotensi menimbulkan kerumunan massa. Untuk itu pembelajaran konvensional yang mengumpulkan banyak siswa dalam satu ruangan perlu ditinjau ulang pelaksanaannya. Pembelajaran harus dilaksanakan dengan skenario yang mampu meminimalisir kontak fisik antara siswa dengan siswa lain, ataupun antara siswa dengan guru.

Menurut Milman (dalam Septiawan, 2020) penggunaan teknologi digital memungkinkan siswa dan guru berada di tempat yang berbeda selama proses pembelajaran. Salah satu platform yang digunakan dalam evaluasi proses pembelajaran di SMA Negeri 1 Candiroto adalah Google Form. Menurut Rahardja (2018) platform ini umumnya dimanfaatkan untuk mengisi data yang mudah dan efektif. Menambahkan fitur dari Google Form sangat mudah dan ramah diakses oleh pengguna dalam hal ini siswa. Begitu juga menurut Batubara (2016) Penggunaan Google Form sebagai alat penilaian proses pembelajaran juga mendukung program penghematan kertas sebagai wujud peduli lingkungan. Selain itu, tenaga dan waktu yang diperlukan guru untuk menyebarkan angket dan mengolah datanya lebih hemat dan mudah.

Beberapa peneliti sebelumnya yang membahas mengenai penggunaan Google Form pada penelitian Sianipar (dalam Septiawan,2020) menunjukkan respon yang positif terhadap penggunaan Google Form sebagai alat penilaian kepuasan pelayanan mahasiswa. Selain itu juga, penelitian Amalia (2019) menyatakan pemanfaatan platform Google Form sebagai media untuk bahan evaluasi sangat praktis sekali selain sangat praktis, penggunaan platform Efektivitas Penggunaan Google Form dalam Pembelajaran Daring 131 Google Form juga memudahkan guru dalam memberikan nilai kepada siswa dan memiliki fitur quiz yang dapat memberi skor pada jawaban atas pertanyaan yang diberikan. Berdasarkan uraian diatas, penelitian ini berfokus untuk melihat efektivitas penggunaan Google Form dalam pembelajaran daring pada mata pelajaran Bahasa Jawa.

Google Form atau google formulir adalah alat yang berguna untuk membantu merencanakan acara, mengirim survei, memberikan siswa atau orang lain kuis, atau mengumpulkan informasi yang mudah dengan cara yang efisien. Form dapat dihubungkan ke spreadsheet. Jika spread sheet terkait dengan bentuk, tanggaanpan otomatis akan dikirimkan ke spreadsheet. Jika tidak, pengguna dapat melihat mereka di "Ringkasan Tanggapan" halaman dapat diakses dari menu Tanggapan. Google Form merupakan salah satu komponen layanan 
Google Docs. Aplikasi Google Form sangat sesuai untuk mahasiswa, guru, dosen, pegawai kantor dan professional yang sering membuat quiz, form dan survey online. Fitur Google Form dapat di bagi kepada orang lain secara terbuka atau khusus kepada pemilik akun Google dengan pilihan aksesibilitas, seperti: read only (hanya dapat membaca) atau editable (dapat mengedit dokumen). Beberapa fungsi Google Form di dunia pendidikaan antara lain: 1) Memberikan tugas latihan/ ulangan online melalui laman website, 2) Mengumpulkan pendapat orang lain melalui laman website, 3) Mengumpulkan berbagai data siswa/ guru melalui halaman website, 4) Membuat formulir pendaftaran online untuk sekolah, 5) Membagikan kuesioner kepada orang-orang secara online(Hamdan Husein Batubara, 2016:40-41).

Penelitian ini penting dilakukan karena bertujuan untuk mengetahui penggunaan Google Form yang sangat bermanfaat dan membantu dalam proses pelaksanaa evaluasi belajar peserta didik di masa pandemic Covid-19 mengingat guru mengalami berbagai kendala dalam menentukan instrument penilaian yang tepat di masa pandemi karena kegiatan pembelajarannya tidak bisa dilaksanakan secara tatap muka akan tetapi secara daring.

\section{METODE PENELITIAN}

Penelitian ini menggunakan pendekatan kualitatif. Tujuan penelitian ini untuk mengetahui keefektifan penggunan Google Form dalam evaluasi belajar di era pandemic Covid 19. Subyek dari penelitian ini adalah peserta didik kelas XII MIPA1 Tahun Ajaran 2021/2022 di SMA Negeri 1 Candiroto, kabupaten Temanggung. Teknik pengambilan data dilakukan dengan angket melalui apikasi Google Form yang linknya dishare lewat WA group kelas . Ada 35 peserta didik yang menjadi responden dan mereka memberikan jawaban sesuai dengan kondisi yang sebenarnya.

Menurut hasil penelitian Septiawan (2020), bahwa penelitian yang tidak memberikan kontrol terhadap subjek sebagai responden yang diteliti berarti data diambil berdasarkan keadaan nyata sesuai fakta yang ada.

\section{HASIL DAN PEMBAHASAN}

\section{Hasil Angket Siswa}

Berdasarkan data angket yang diisi oleh peserta didik sebagai responden, maka diperoleh hasil yang akan mejadi pembahasan dan menjawab identifikasi masalah yang telah dirumuskan sebelumnya dari penelitian penggunaan Google Form dalam evaluasi hasil belajar peserta didik pada masa pandemic Covid-19 di SMA Negeri 1 Candiroto Kabupaten Temanggung. Dari deskripsi data angket, maka selanjutnya akan direkapitulasi, berikut ini data yang diperoleh dari hasil angket kepada 35 siswa sebagai responden :

Tabel 1. Hasil Angket Efektivitas Penggunaan Google Form

\begin{tabular}{|c|c|c|c|c|c|c|c|}
\hline \multirow[t]{2}{*}{ No } & \multirow[t]{2}{*}{ Pernyataan } & \multicolumn{4}{|c|}{ Jawaban } & \multirow{2}{*}{$\begin{array}{l}\text { Jumlah } \\
\text { Skor }\end{array}$} & \multirow{2}{*}{$\begin{array}{l}\text { Persentase } \\
\quad(\%)\end{array}$} \\
\hline & & SS & $\mathbf{S}$ & TS & STS & & \\
\hline 1 & $\begin{array}{l}\text { Platform Google Form mudah } \\
\text { saya gunakan }\end{array}$ & 60 & 60 & 0 & 0 & 120 & 85.71 \\
\hline 2 & $\begin{array}{l}\text { Dalam menggunakan Google } \\
\text { Form sering terkendala kuota } \\
\text { internet }\end{array}$ & 6 & 36 & 30 & 0 & 72 & 51.43 \\
\hline 3 & $\begin{array}{l}\text { Google Form mempermudah } \\
\text { saya sebagai siswa dalam } \\
\text { mengerjakan ulangan daring }\end{array}$ & 44 & 12 & 6 & 0 & 62 & 44.29 \\
\hline 4 & $\begin{array}{lcc}\text { Google Form dalam ulangan } \\
\text { harian daring } & \text { kurang } \\
\text { memotivasi saya dalam belajar }\end{array}$ & 2 & 16 & 36 & 16 & 70 & 50.00 \\
\hline
\end{tabular}


TEACHING : Jurnal Inovasi Keguruan dan IImu Pendidikan

Vol. 1. No. 3 September 2021 e-ISSN : 2775-7188 | p-ISSN : 2775-717X

\begin{tabular}{|c|c|c|c|c|c|c|c|}
\hline 5 & $\begin{array}{l}\text { Dalam menggunakan Google } \\
\text { Form sering terkendala sinyal }\end{array}$ & 52 & 39 & 18 & 0 & 109 & 77.86 \\
\hline 6 & $\begin{array}{l}\text { Dengan Google Form } \\
\text { mengerjakan ulangan lebih cepat } \\
\text { selesai }\end{array}$ & 56 & 60 & 2 & 0 & 118 & 84.29 \\
\hline 7 & $\begin{array}{l}\text { Saya sebagai siswa dapat } \\
\text { mengerjakan ulangan daring } \\
\text { dimanapun }\end{array}$ & 52 & 51 & 10 & 0 & 113 & 80.71 \\
\hline 8 & $\begin{array}{l}\text { Pembelajaran menggunakan } \\
\text { Google Form lebih menarik } \\
\text { dibandingkan pembelajaran tatap } \\
\text { muka di sekolah }\end{array}$ & 52 & 57 & 6 & 0 & 115 & 82.14 \\
\hline 9 & $\begin{array}{l}\text { Pembelajaran tatap muka tidak } \\
\text { perlu,karena } \\
\text { menggunakan } \\
\begin{array}{l}\text { sudah cukup } \\
\text { sudagla }\end{array}\end{array}$ & 68 & 36 & 0 & 0 & 104 & 74.29 \\
\hline 10 & $\begin{array}{l}\text { Menggunakan Google Form bisa } \\
\text { membuat saya menguasai materi } \\
\text { pembelajaran lebih } \\
\text { Mudah }\end{array}$ & 36 & 63 & 8 & 1 & 108 & 77.14 \\
\hline 11 & $\begin{array}{l}\text { Walaupun tidak sekolah saya } \\
\text { masih bisa belajar dengan } \\
\text { menggunakan Google Form }\end{array}$ & 16 & 72 & 10 & 2 & 100 & 71.43 \\
\hline 12 & $\begin{array}{l}\text { Belajar menggunakan Google } \\
\text { Form membuat saya bisa bergaul } \\
\text { dengan teman seusianya }\end{array}$ & 4 & 48 & 32 & 2 & 86 & 61.43 \\
\hline 13 & $\begin{array}{l}\text { Penggunaan Google form lebih } \\
\text { memotivasi saya dalam belajar }\end{array}$ & 12 & 69 & 16 & 1 & 98 & 70.00 \\
\hline 14 & $\begin{array}{l}\text { Penggunaan Google Form } \\
\text { membuat saya lebih terampil } \\
\text { menggunakan sarana } \\
\text { teknologi dan informasi }\end{array}$ & 64 & 57 & 0 & 0 & 121 & 86.43 \\
\hline 15 & $\begin{array}{l}\text { Penggunaan Google Form } \\
\text { mengembangkan kreatifitas saya } \\
\text { dalam belajar }\end{array}$ & 28 & 66 & 12 & 0 & 106 & 75.71 \\
\hline 16 & $\begin{array}{l}\text { Dengan Google Form membuat } \\
\text { saya sulit dalam mengumpulkan } \\
\text { ulangan }\end{array}$ & 0 & 3 & 90 & 20 & 113 & 80.71 \\
\hline 17 & $\begin{array}{l}\text { Hasil belajar menggunakan } \\
\text { Google Form lebih baik }\end{array}$ & 4 & 66 & 22 & 0 & 92 & 65.71 \\
\hline 18 & $\begin{array}{l}\text { Saya bisa cepat mengetahui hasil } \\
\text { belajar dengan Google Form }\end{array}$ & 40 & 69 & 4 & 0 & 113 & 80.71 \\
\hline 19 & $\begin{array}{l}\text { Menggunakan Google Form } \\
\text { membutuhkan biaya yang mahal }\end{array}$ & 0 & 10 & 72 & 24 & 106 & 75.71 \\
\hline 20 & $\begin{array}{l}\text { Google Form membuat saya sulit } \\
\text { mengajukan pertanyaan bila ada } \\
\text { yang kurang dimengerti }\end{array}$ & 4 & 46 & 18 & 8 & 76 & 54.28 \\
\hline
\end{tabular}

Sumber: Data primer diolah, Tahun 2020

Berikut adalah data berdasarkan rekapan jawaban responden sejumlah 35 siswa kelas XI MIPA-1 SMA Negeri 1 Candiroto, Kabupaten Temanggung Tahun ajaran 2021/2022 sesuai dengan empat indikator soal. 
TEACHING : Jurnal Inovasi Keguruan dan IImu Pendidikan

Tabel 2. Persentase Indikator Angket Efektivitas Penggunaan Google Form

\begin{tabular}{|c|l|c|c|}
\hline No & \multicolumn{1}{|c|}{ Indikator } & Rata-rata & $\begin{array}{c}\text { Persentase } \\
(\%)\end{array}$ \\
\hline 1 & $\begin{array}{l}\text { Penggunaan Google Form sebagai media } \\
\text { pembelajaran. }\end{array}$ & 643 & 61.86 \\
\hline 2 & $\begin{array}{l}\text { Perbandingan pembelajaran Google Form dengan } \\
\text { pembelajaran tatap muka. }\end{array}$ & 558 & 79.71 \\
\hline 3 & $\begin{array}{l}\text { Penggunaan Google Form meningkatkan kemampuan } \\
\text { siswa dalam Teknologi dan Informasi Komunikasi }\end{array}$ & 511 & 73.00 \\
\hline 4 & $\begin{array}{l}\text { Hasil belajar siswa setelah menggunakan } \\
\text { Google Form Jumlah rata-rata }\end{array}$ & 2.002 & 71.43 \\
\hline \multicolumn{1}{|c|}{ J } & & \\
\hline
\end{tabular}

Sumber: Data primer diolah, Tahun 2020

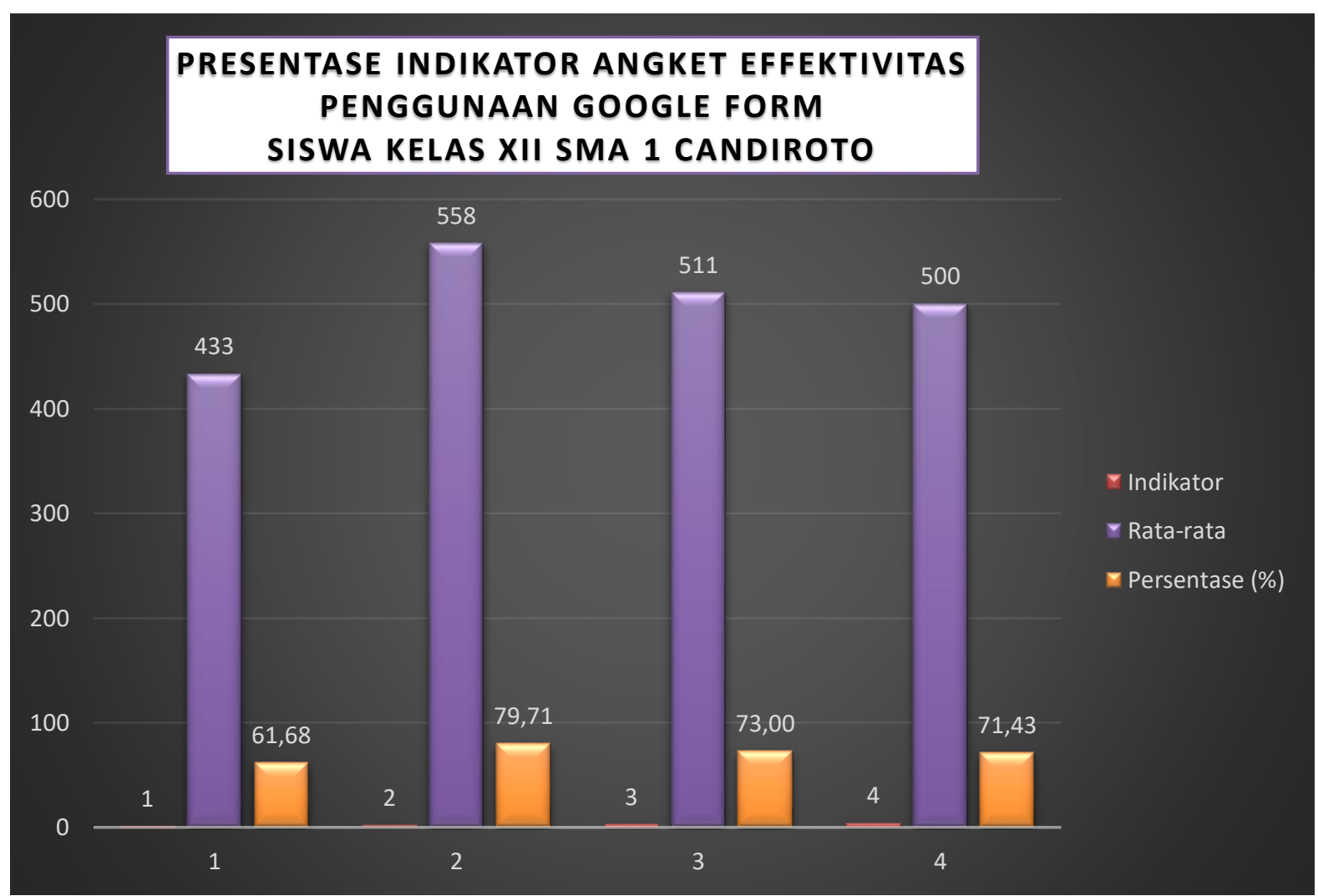

Gambar 1. Persentase Indikator Angket Efektivitas Penggunaan Google Form

\section{Pembahasan}

Berdasarkan data diatas siswa merespon dengan baik terhadap penggunaan aplikasi Google Form sebagai media pembelajaran khususnya untuk pelaksanaan evaluasi belajar siswa di masa pandemic Covid-19. Efektivitas penggunaan Google Form untuk pelaksanaan evaluasi belajar siswa kelas XII-MIPA1 SMA Negeri 1 Candiroto, kabupaten Temanggung tahun ajaran 2021/2022 sejumlah 35 siswa yang menjadi responden dari hasil rekapitulasi yang terdiri dari 4 indikator yang diuraikan menjadi 20 pertanyaan, perolehan hasil baik dengan rata-rata yaitu $71.50 \%$.

\section{Efektivitas Penggunaan Google Form}

Pembelajaran daring yang dilaksanakan di SMA Negeri 1 Candiroto sebagai upaya untuk memutus rantai penyebaran Covid-19 dilaksanakan menggunakan aplikasi pembelajaran 
e-learning . E-learning dapat membantu guru dalam memantau keaktifan siswa dalam penugasan dan ulangan harian. Siswa juga merasa puas dalam melaksanakan evaluasi belajar di masa yang penuh keterbatasan untuk dilakukan tatap muka selain itu juga meningkatkan kemampuan siswa dalam penggunaan Teknologi Informasi dan Komunikasi. Siswa tidak terikat ruang dan waktu karena mereka bisa mengerjakan ulangan dimana saja. Menurut Septiawan (2020), menyatakan bahwa Google Form sebagai salah satu aplikasi berupa template formulir atau lembar kerja yang dapat dimanfaatkan oleh guru maupun siswa untuk tujuan khususnya dalam pemebelajaran.

Untuk membuka soal Google Form siswa dapat mengakses lewat Classroom atau group WA (whatsapp) atau group telegram kelas tergantung guru yang mengeshare link soal tersebut. Sedangkan media untuk mengerjakan adalah $\mathrm{hp}$ android atau laptop yang keduanya tersambung sinyal yang bagus. Penggunaan Google Form sangat mudah dibuat dan diaplikasikan kedalam pembelajaran jarak jauh dimasa Pandemi Covid -19. Kelebihan menggunakan Google Form untuk alat tes yang hasilnya atau nilainya bisa langsung diketahui dengan cepat sehingga bisa melaksanakan tindak lanjut berupa remidial dan pengayaan dan juga data kehadiran siswa bisa terpantau.

Kendala

Beberapa kendala yang ditemui ketika pembelajaran jarak jauh antara lain : 1) tidak semua siswa tinggal di wilyah yang terjangkau jaringan internet yang bagus ; 2) kuota yang dimiliki siswa terbatas ; 3) Sulit memantau apakah siswa mengerjakan ulangan harian sendiri ; 4) fasilitas hp android siswa dengan memori yang terbatas.

\section{Pembelajaran Jarak Jauh}

Melalui pembelajaran jarak jauh guru melakukan evaluasi belajar siswa melalui kelaskelas vitual yang dapat diakses dimanapun dan kapanpun. Untuk membuka soal Google Form siswa dapat mengakses lewat Classroom atau group WA (whatsapp) atau group telegram kelas tergantung guru yang mengeshare link soal tersebut. Sedangkan media untuk mengerjakan adalah hp android atau laptop yang keduanya tersambung sinyal yang bagus.

Hasil penelitian menunjukan bahwa siswa melalui Google Form sebagai media evaluai belajar mempermudah dalam mengerjakan ulangan dan langsung dapat mengetahui hasil belajarnya , meningkatkan kemampuan dalam menggunaka sarana teknologi dan informatika. Selain itu hasil tanggapan siswa yang menyatakan bahwa sering terkendala sinyal internet dan membutuhkan biaya yang mahal adalah tantangan tersendiri dalam pembelajaran jarak jauh.

\section{KESIMPULAN}

Berdasarkan analisis dan pembahasan dari hasil angket yang telah dibagikan kepada siswa sejumlah 35 siswa kelas XII-MIPA 1 sebagai responden maka dapat disimpulkan bahwa efektivitas penggunaan Google Form dalam evaluasi hasil belajar siswa SMA Negeri1 Candiroto adalah positif khususnya untuk pelaksanaan ulangan harian dengan perolehan persentase rata-rata $71.50 \%$ kategori baik. Google form mempermudah siswa dalam mengerjakan ulangan harian, mengerjakan tugas dan meningkatkan siswa dalam menggunakan teknologi dan informasi serta lebih cepat mengetahui hasil belajar. Ada beberapa hasil respon siswa yang menyatakan sering terkendala sinyal internet dan keterbatasan kuota internet karena biaya yang mahal itu merupakan tantangan tersendiri dalam pembelajaran jarak jauh.

\section{DAFTAR PUSTAKA}

Amalia, (2019). Penggunaan Media Google Form Dalam Evaluasi Pembelajaran Bahasa Arab Maharah Kitabah. Prosiding Konferensi Nasional Bahasa Arab V. http://prosiding.arab-um.com/index.php/konasbara/article/view/50

Batubara, H. H. Penggunaan Google Form Sebagai Alat Penilaian Kinerja Dosen di Prodi PGMI Uniska Muhammad ArsyadAl Banjari. Al-Bidayah: Jurnal Pendidikan Dasar Islam V8, No.1 Juni 2016; ISSN : 2085-0034 
Charolina,Y. \& Honny (2021). Pemanfaatan Aplikasi Googleform Dalam Pembelajaran Bagi Guru Pada Masa Pandemi: Akreditasi Ristekdikti, No: 30/E/KPT/2019 (Sinta 4). Vol. 23, No. 1 from DOI: https://doi.org/ 10.31294/p.v23i1.10092

Darmayanti, T.,setiani, M.Y.,\& Oetoyo, B. ( 2007). E- Learning Pada Pendidikan Jarak Jauh : Konsep yang Mengubah Metode Pembelajaran I Perguruan Tinggi Di Indonesia. Jurnal Pendidikan terbuka dan Jarak Jauh, 8(2).

Hakim, AB. (2016). Efektifitas Penggunaan Elearning Moodle, Google Classroom DanEdmodo. I-statement :information systemand technology management, 2(1): 24428337

Matondang Z.,Djulia E.,Sriadhi \& Simartama J. (2019).Evaluasi Hasil Belajar.Yogyakarta. Yayasan Kita Menulis.

Milman, N. B. (2015). Distance Education. In International Encyclopedia of the Social \& Behavioral Sciences: Second Edition. https://doi.org/10.1016/B978-0-08-097086 8.920014

Mulatsih B. (2020). Penerapan Aplikasi Google Classroom, Google Form, Dan Quizizz Dalam Pembelajaran Kimia Di Masa Pandemi Covid-19. Ideguru : Jurnal Karya Ilmiah Guru Vol. 5, No.1 Edisi Khusus KBM Pandemi COVID-19

Rahardja, U, dkk. (2018). Pemanfaatan Google Formulir sebagai Sistem Pendaftaran Anggota pada Website Asosiasi. Media Informatika Budidarma, Vol 2, no. 4,Oktober 2018.

Septiawan,F.(2020). Efektivitas Penggunaan Goofle Form Dalam Pembelajaran Daring Pada Mata Pelajaran Pemeliharaan Mesin Sepeda Motor Di SMK Negeri 1 Koba : Jurnal Pendidikan Teknik Mesin. Volume 7 nomor 2 hal 129-135

Sianipar, (2019). Penggunaan Google Form Sebagai Alat Penilaian Kepuasan Pelayanan mahasiswa. Journal of Information System, Applied, Management, Accounting and Research Vol. 33 no. 1

Weni. D. M,. \& Isnani, G (2016). Meningkatkan Hasil Belajar Siswa dengan PengembanganMedia Pembelajaran . jurnal pendidikan bisnis dan Manajemen 2(2). 